\title{
Arabiske omvæltninger presser EU's åbne grænser
}

Michael Seidelin

\section{Schengen-samarbejdet med de åbne grænser mellem flertallet af EU-landene er under angreb. Danmark fører an, og højrepartier i Europa jubler}

Politikere fra fem europæiske lande skålede og holdt flotte taler, da de i 1985 markerede en ny etape i det europæiske samarbejde. Nu skulle grænsebommene, symbolet på nationalstaternes Europa, falde. I første omgang skulle bevogtningen ved grænserne lettes, som Frankrig og Tyskland allerede havde besluttet det året før. Men målet var åbne grænser, lød det fra deltagerne i mødet i den romantiske lilleby Schengen i Luxembourg i hjørnet mellem Luxembourg, Frankrig og Vesttyskland.

Symbolikken blev yderligere understreget ved, at mødet mellem de tre lande samt Holland og Belgien fandt sted på en floddamper på Mosel-floden, som løber gennem flere af landene. 'Store europæere' som Frankrigs præsident François Mitterrand, den vesttyske forbundskansler Helmut Kohl og Europa-Kommissionsformand Jacques Delors så afta- len som et vigtigt led i den europæiske integration, som nåede en foreløbig kulmination fem år senere med Maastricht-traktaten.

I dag er Schengen nærmest et skældsord i flere EU-lande. Omvæltningerne i en række arabiske lande er med til at få Danmark og Frankrig til at indføre skærpede foranstaltninger ved grænserne, Holland indfører særlige regler for tunesere, og partier fra det nationalistiske højre, som i Frankrig, Schweiz og $\emptyset$ strig repræsenterer $20-29$ pct. af vælgerne ved de seneste valg og for Frankrigs vedkommende i meningsmålinger, kræver Schengen-aftalen helt afskaffet.

\section{Tilbagetog}

EU-forskeren Amandine Crespy fra Université Libre de Bruxelles og Harvard ser i en kommentar i det franske dagblad Le Monde et forsøg 
på at ribbe dele af det europæiske integrationsmønster op. Og hun peger på, at en svag Europa-Kommission ikke har reageret, når de 'store lande', som hun formulerer det, forsøger at rulle etablerede resultater og regler tilbage.

"Man må stille spørgsmålet, om ankomsten af 25.000 tunesere i Europa virkelig udgør en exceptionel situation, som retfærdiggør suspensionen af fundamentale regler for unionens virke. Under konflikterne i det tidligere Jugoslavien stod Tyskland alene over for en langt større tilstrømning af flygtninge. Tiderne har tilsyneladende ændret sig”, skriver Amandine Crespy.

Denne udvikling kommer ikke overraskende - for et er politiske visioner og idealer, noget andet er realiteter og frygt for visse vælgergrupper, når uforudsete begivenheder som det arabiske oprør viser sig.

Som den nu afdøde britiske historiker Tony Judt skriver i sit monumentale værk Postwar. A History of Europe since 1945 indeholdt aftalen fra 1985 nemlig også et element, som hed styrkelse af deltagerlandenes ydre grænser som kompensation for de åbne grænser indadtil, og ifølge Judt viste dette krav en vis 'provinsialisme'. "Civiliserede europæere kunne overskride grænser men 'barbarerne' blev meget bestemt holdt tilbage bag dem", skriver Tony Judt, og hans skepsis blev bekræftet i vinteren og foråret 2011.

Vi oplevede ikke alene kravene om øget grænsekontrol. Ud over dem afviste EU's indenrigs- og justitsministre i juni 2011 Bulgariens og Rumæniens deltagelse i samarbejdet med den begrundelse, at de to landes indsats mod organiseret kriminalitet ikke var tilstrækkelig, og at nødvendige reformer af retsvæsenet endnu ikke var gennemført. Det skete på trods af, at Europa-Parlamentet med stort flertal foreslog optagelsen af de to EU-lande i Schengen-samarbejdet.

\section{Arabisk 'folkevandring'}

Andre begivenheder ledte også tanken hen på Tony Judts bemærkninger om åbningen af de europæiske grænser. I Danmark vedtog Folketinget trods advarsler fra Europa-Kommissionen og trods protester og spydige bemærkninger fra nabolande som Tyskland og Sverige sidst i juni at indføre en begrænset grænse- og toldkontrol ved landets ydre grænser, og hele foråret havde især Frankrig krævet en stramning af Schengen-reglerne.

Franskmændene havde allerede taget forskud på eventuelle nye regler ved i marts at indføre en kontrol af rejsende mellem Italien og Frankrig på grænsen mellem Menton på den franske del af Côte d' Azur og Ventimiglia i Italien.

Baggrunden var revolutionerne på den anden side af Middelhavet. Den italienske regering frygtede en 'flodbølge' af illegale indvandrere 
og flygtninge fra især Tunesien efter omvæltningerne i landet ved årsskiftet og den efterfølgende forværring af landets økonomi.

På et tidspunkt talte den franske regering om 15.000 mulige indvandrere, som ville forsøge at nå Frankrig fra Italien. For de illegale indvandrere, der med fare for deres liv krydsede Middelhavet i alt fra trawlere til primitive motorbåde, ønskede stort set alle at komme videre fra Italien til Frankrig, Belgien, Holland og Tyskland.

Det var muligt, for Italien giver asylansøgere og illegale indvandrere midlertidige opholdstilladelser for ikke at samle udlændingene sammen i store lejre i længere tid ad gangen. Og i realiteten kan asylansøgere og illegale indvandrere bevæge sig frit videre få dage efter ankomsten til Italien.

Men invasionen af 'bibelske dimensioner', som Italiens indenrigsminister Roberto Maroni fra det indvandrerfjendske autonomistparti Lega Nord kaldte 'den arabiske folkevandring', udeblev.

Mellem januar og maj 2011 kom omkring 25.000 indvandrere, flygtninge og asylansøgere til Italien. Umiddelbart så billederne fra øen Lampedusa, hvor de fleste kom i land, dramatiske ud. Men italienerne fik hurtigt etableret optagelseslejre i det sydlige Italien, og i april og maj blev illegale indvandrere og i stigende grad flygtninge fra krigshandlingerne i Libyen sejlet fra
Lampedusa og Sicilien til Genoa og andre norditalienske havnebyer.

Italien viste sig altså at være $\mathrm{i}$ stand til at opsuge denne indvandring, hvilket eksperter, repræsentanter for humanitære organisationer og kommentatorer i månedsvis havde hævdet var muligt.

Kommentatoren Piero Ignazi mindede fx i ugemagasinet l'Espresso 21. april $2011 \mathrm{om}$, at alene Tunesien har modtaget over 200.000 flygtninge fra Libyen, og at mindre EU-lande som Grækenland, Belgien og Holland forholdsmæssigt modtager langt flere end Italien. "Regeringen beskylder EU for at lade Italien stå alene over for indvandrerne. Men den gjorde ikke noget, da Grækenland, Sverige og Tyskland skulle tage imod endnu flere", skrev Piero Igna$\mathrm{zi}$, hvis dom over regeringen var hård: "Også i dette spørgsmål har den italienske regering formået at forringe vores i forvejen ikke strålende internationale anseelse".

\section{Pandoras æske}

I hele dette forløb anklagede Italien EU for ikke at tage højde for 'frontlinjestaternes' problemer. Men et andet Middelhavsland, Spanien, klagede ikke, og flertallet i EU var imod at åbne den Pandoras æske, som hedder EU's flygtninge- og indvandrerpolitik. Den har været svær at få på plads, den er stadig ufuldstændig og en række lande, herunder Danmark, står udenfor. 
"Hvis man kan forbedre Schengen-systemet, så er det godt og så skal man gøre det. Men rejsefriheden i Europa er et så vigtigt resultat, at det ikke bør genforhandles”, lød det fra den tyske udenrigsminister Guido Westerwelle i april, og han var ligeså fast, da han i juni modtog udenrigsminister Lene Espersen (K) i Berlin, da hun forsøgte at vinde forståelse for den danske beslutning om at styrke grænsekontrollen.

Guido Westerwelles reaktion afspejler bekymringen i Bruxelles og flere EU-hovedstæder, for situationen kan hurtigt komme ud af kontrol.

I begyndelsen af marts skærpede Frankrig som næunt bevogtningen af grænsen mellem Ventimiglia i Italien og Menton i Frankrig for at hindre nordafrikanere $i$ at overskride grænsen. Bl.a. stoppede politiet tog umiddelbart inden ankomsten til Menton, og udlændinge uden gyldige papirer blev ført ud af toget og midlertidigt anbragt i såkaldte 'tilbageholdelsescentre', indtil flertallet blev sendt tilbage til Italien.

Ifølge Italien skabte Frankrig hindringer for den fri bevægelighed ved grænsen, hvilket er i strid med Schengen. Franskmændene derimod pegede på bestemmelser $\mathrm{i}$ traktaten, som åbner for en begrænset kontrol i exceptionelle tilfælde, og Europa-Kommissionen accepterede denne forklaring samtidig med, at Frankrig med præsident Nicolas Sarkozys ord ønskede forhand- linger om 'fleksibilitet' i aftalen.

Et møde mellem regeringschef Silvio Berlusconi og Nicolas Sarkozy lagde en dæmper på stridighederne med en udtalelse om, at begge lande ønsker ændringer i samarbejdet, og de fik hurtigt støtte fra Tyskland, Holland, Finland og Østrig, der ligesom nu Danmark kræver ret til at genetablere kontrollen ved EU's indre grænser i særlige situationer.

Den franske reaktion kom efter en stribe politiske markeringer fra præsidentens side, som alle handlede om nødvendigheden af at hindre 'ukontrolleret' indvandring, sideløbende med kampagner fra præsidentens parti, Union pour la Majorité Présidentielle, mod den ifølge præsidenten stadig mere massive tilstedeværelse af romaer fra Balkanlandene i Frankrig.

De faldt også sammen med offentliggørelsen af meningsmålinger som viste, at det fremmedfjendske parti Front Nationals nye leder, Marine Le Pen, stod til at samle 20-22 pct. af vælgere i første omgang af præsidentvalget i april-maj 2012.

\section{DF går i spidsen}

Sagen er nemlig, at Schengen-debatten overalt i Europa er drevet frem af partier, som tilhører det nationalistiske højre.

Det var tilfældet i Danmark, hvor Dansk Folkeparti stillede krav om øget grænsekontrol som den politiske betaling for at støtte regeringens 
$ø$ konomiske program. En række politiske kommentatorer pegede på, at Dansk Folkeparti valgte at hive et sikkert kort som kombinationen af EU-modstand, frygt for indvandring og grænseoverskridende kriminalitet frem i en situation, hvor indrømmelser til regeringen omkring efterlønnen havde stillet partiet i en vanskelig situation. Måske derfor var Dansk Folkeparti tilfreds, da aftalen med regeringen var i hus.

"Ude i vores bagland vil man helt sikkert kunne se lignende reaktioner. Faktisk var der en i partiet, der tidligere i dag sagde til mig, at dette her er på linje med dengang, der blev stemt nej til euro'en i 2000. Det er to sider af samme sag, nemlig kampen for at nationalstaten gerne må have nogle egne kendetegn, og at de ikke bliver helt udviskede i 'Europas Forenede Stater", lød det fra Kristian Thulesen Dahl fra partiets ledelse.

Front National i Frankrig var også begejstret. Partiet reagerede meget hurtigt på den danske regerings tanker om en styrkelse af grænsekontrollen i form af en udtalelse fra partileder Marine Le Pen.

"Marine Le Pen, formand for Front National, hilser den danske regerings beslutning om at genoprette kontrollen ved landets faste og maritime grænser. Stillet over for tilstrømningen af tunesiske og libyske udvandrere forsvarer Danmark blot landets legitime, nationale interesser". I udtalelsen understreger Marine
Le Pen, hvis parti oplever en stærk tilstrømning af medlemmer efter valget af hende til partileder i januar, at Danmarks holdning "er i stærk modstrid med Nicolas Sarkozy-regeringens snik-snak og totale passivitet... På længere sigt er den eneste mulighed at forlade Schengen”.

Partiets generalsekretær, Steeve Briois, så også store perspektiver i det danske initiativ.

"Det er meget afgørende, at Danmark nu rejser spørgsmålet. Det vil hjælpe andre til for alvor at sætte problemet med de åbne grænser på dagsordenen", sagde han til Politiken.

De samme toner lyder i Schweiz. Landet står uden for EU, men det deltager i Schengen-samarbejdet, og det skal være slut nu, mener Toni Brunner, formand for Det Schweiziske Folkeparti, SVP, som ved valget i 2007 fik 29 pct. af stemmerne.

"Det er på høje tid, at SVP indleder kampen for at genvinde kontrollen med indvandringen og begrænse tilstrømningen af udlændinge", sagde Toni Brunner.

Tidligere på året forlangte partiet en genforhandling af Schengentraktaten. "Hvis en 'opting out' efter irsk og britisk model ikke er mulig, skal Schweiz opsige aftalen", lyder det i en udtalelse fra partiet, som i stadig højere grad sætter dagsordenen i Schweiz.

I Holland var meldingen fra Geert Wilders Frihedsparti, der som Dansk Folkeparti er parlamentarisk grund- 
lag for en borgerlig regering, ligeså klar:

"Vi er meget enige med Dansk Folkeparti i, at grænsekontrollen skal styrkes. Derfor er den danske aftale godt nyt: Jo mere, der skubbes på, jo bedre. Vi har bedt regeringen her om at sige klart i EU, at der bør skabes mulighed for mere grænsekontrol inden for Schengen", sagde partiets indvandringsordfører, Sietse Fritsma, til Politiken, og Holland er allerede ved at styrke bevogtningen umiddelbart bag grænsen.

Lignende toner lød fra Frihedspartiet i Østrig, der ifølge flere meningsmålinger ligger til at blive landets største parti ved næste valg.

"Vi har hilst den danske beslutning om genindførelse af grænsekontrol og delvis suspendering af Schengen-aftalen velkommen", udtalte Karl-Heinz Grünsteidl, der sidder i den østrigske nationalforsamling for Frihedspartiet, FPÖ, i samme artikel i Politiken.

I Italien var situationen speciel. For normalt er det indvandrerfjendske parti Lega Nord, der deltager i den italienske regering, skeptisk over for åbne grænser og alt, hvad der kan lette indvandreres muligheder for at bevæge sig.

Men lige nu har partiet det svært, mener den politiske kommentator, historikeren Paolo Borioni.

"Det hænger sammen med, at Italiens vigtigste grænse udadtil er en meget lang kyststrækning", forklarer han. Mange indvandrere og flygt- ninge kommer ind ad den vej, og mange vil videre til Frankrig, Tyskland og Nordeuropa. Italien ønsker ikke at beholde dem.

Men generelt er billedet klart. Højrenationalistiske partier i Europa har blæst til modstand mod de åbne grænser, og det bliver et tema i deres valgkampe.

\section{Krise eller 'as usual'?}

Spørgsmålet er så, om vælgerne er med? De første meningsmålinger i Danmark tyder ikke på det. Ifølge markante borgerlige skikkelser som tidligere udenrigsminister Uffe Ellemann-Jensen og tidligere forsvarsminister Hans Engell har både Dansk Folkeparti og regeringen skudt sig selv i foden med et initiativ, der kalder på en blanding af indignerede og spydige kommentarer fra to af vores vigtigste $ø$ konomiske og politiske partnere, Tyskland og Sverige.

Men de nationalistiske højrepartier har lagt et nyt redskab i deres politiske værktøjskasse, og de kan i de kommende måneder og år skrue op og ned for Schengen-retorikken og kritikken af EU i takt med de øjeblikkelige politiske behov og konjunkturer.

I forvejen har EU det svært i disse år. En gennemgående klagesang handler om, at fortidens store ledere som Jacques Delors, François Mitterrand, Helmut Schmidt og Helmut Kohl er afløst af mænd og kvinder uden visioner for Europa. Især 
forbundskansler Angela Merkel står for skud pga. hendes tøvende håndtering af først finanskrisen i 20092010 og så den græske krise i 2011.

Historikeren Timothy Garton Ash tegnede det op på denne måde i en kommentar i dagbladet The Guardian 15. juni i år.

Det er ikke kun krise i eurozonen, skrev han med henvisning til EUlandenes mildt sagt vaklende og usikre politik i forhold til den græske (og i mindre omfang andre EUlandes) gældskrise og desperate forsøg på at undergå total økonomisk fallit.

“Hvert af EU's større projekter falder fra hinanden. Frankrig og Italien antyder, at gennemførelsen af Schengen-området uden grænsekontrol skal opgives - blot fordi nogle få tusinde mennesker fra det urolige Nordafrika er flygtet til den italienske ø Lampedusa. Mange europæiske lande er allerede nu paniske over integrationen af indvandrere og mennesker med indvandrerbaggrund, specielt når det drejer sig om muslimer. Den angst er skærpet af det arabiske forår.

Solidaritet og social retfærdighed - centrale værdier i det europæiske projekt efter 1945 - er i tilbagegang næsten overalt som resultatet af voksende ulighed og besparelser, som skal nedskære den offentlige gæld", skrev Timothy Garton Ash .

Daniel Cohn-Bendit, gruppeformand for De Grønne i Europa-Parlamentet, taler om et forsøg på at ribbe den europæiske integration fra hinanden, som det ifølge ham allerede skete i forbindelse med de seneste udvidelser af EU. "Man lavede særlige beskyttelsesforanstaltninger, fordi man var bange for den polske blikkenslager, og nu foreslår man nye, fordi man ikke vil have flygtninge. Men man bør netop møde dette problem med solidaritet", siger han $i$ et interview med nyhedsbureauet AFP.

\section{Schengen anarki}

I et såkaldt Policy Brief taler forskerne Thomas Gammeltoft-Hansen og Julie Herschend Christoffersen fra DIIS, Dansk Institut for Internationale Studier, for "en voksende bekymring for 'Schengen-anarki' i resten af Europa" med henvisning til genetableringen af en vis form for kontrol ved den dansk-tyske grænse og Øresundsforbindelsen. Men de minder samtidig om, at EU-Domstolen har fuld kompetence i Schengen-sager. Det betyder, at domstolen skal afgøre, i hvilket omfang medlemsstater kan indføre særlige regler.

Der er altså en vis grænse for 'anarkiet', men de politiske signaler, som bl.a. Daniel Cohn-Bendit taler om, skaber en vis tillid til medlemslandenes vilje til at sikre fortsat integration i situationer, hvor de af indenrigspolitiske grunde ønsker at føre visse kompetencer tilbage til medlemslandene. 
Herover for står den skole af EUpolitikere og EU-forskere, som hæfter sig ved unionens evne til i vanskelige tider at overvinde konflikter og vanskeligheder. Professor Peter Nedergaard svarede i Politiken 17. juni 2011 således på spørgsmålet, om det europæiske samarbejde er i krise:

"Nej. Det europæiske samarbejde er utrolig solidt, og det kan holde til meget. De diskussioner, vi ser internt i EU i øjeblikket, er også et tegn på modenhed og på, at man - ligesom man gør i andre tætte samarbejder har en diskussion mellem centret og delstaterne. EU er på vej til at blive en slags Europas Forenede Stater jeg kalder det somme tider Europas Halvforenede Stater".
"Men EU er og har altid været en mester i at tackle problemer. Man siger, at EU går fra krise til krise. Det er, fordi det er et samarbejde, hvor man er i stand til at løse problemerne. Ellers havde man ikke brugt topmøde efter topmøde på at diskutere disse. Det har man selvfølgelig gjort, fordi man har en forventning om, at vi i det her forum rent faktisk kan løse kriserne. EU er en eminent god kriseløsningsmekanisme”.

Michael Seidelin er Europakorrespondent på Politiken og forfatter til flere bøger om europaisk og amerikansk politik, herunder 'Den stenede vej mod unionen' 2004, og 'Det Hvide Hus og magten i USA' 2008. 